This is a postprint version of the following published document:

García Leiva, M. T. \& Albornoz, L. A. (2020). VOD service providers and regulation in the European Union: an audiovisual diversity approach. International Journal of Cultural Policy, DOI: 10.1080/10286632.2020.1769614

(c) Taylor \& Francis 


\title{
VOD service providers and regulation in the European Union: an audiovisual diversity approach
}

\author{
International Journal of Cultural Policy \\ DOI: $10.1080 / 10286632.2020 .1769614$ \\ $M^{a}$ Trinidad García Leiva \& Luis A. Albornoz \\ Department of Communication, Carlos III University of Madrid, Getafe, Spain
}

\begin{abstract}
A firm step in order to impose a quota for the catalogues of video-on-demand service providers has been given by the EU through the amendment of the Audiovisual Media Services Directive in 2018. This paper aims to analyse the potential implications of this change, in relation to the way the promotion of European works has been implemented so far, since some comments can be made in light of this revision. It will be argued that more interesting than the obligation to comply with a quota, defined by the geographical origin of audiovisual works, is the idea of making VOD service providers part of every national audiovisual production and financing system via direct or indirect financial contributions. It is concluded that indirect obligations could offer a wider room for manoeuvre to better help focus public policy decisions.
\end{abstract}

\section{Keywords}

Cultural diversity. Audiovisual policy. VOD. Quota. Netflix.

\section{Funding \& Acknowledgments}

This work is based on research undertaken for the project 'Audiovisual diversity and online platforms: Netflix as a case study' [CSO2017-83539-R], supported by the State Research Agency (AEI) within the National RDI Program Aimed at the Challenges of Society of the Spanish Ministry of Science, Innovation and Universities, and the European Regional Development Fund (ERDF) of the European Union. 


\section{MAIN TEXT}

\section{Introduction}

One of the debates that has been calling the attention of scholars and policymakers in the field of communication and culture is the regulation of audiovisual contents offered by transnational online platforms through their on-demand catalogues. Public intervention is usually invoked to legally guarantee that video-on-demand (VOD) service providers offer a predetermined percentage of titles or hours of local/regional production in a given market. The aim of this intervention is to secure that locally produced works are available for domestic audiences.

A firm step in order to ensure a share of European works in the catalogues of VOD service providers has been given by the European Union (EU) countries through the amendment of the Audiovisual Media Services Directive (AVMSD) in 2018. This paper aims to analyse the potential implications of this change since some comments can be made in light of this revision from an audiovisual diversity and policy approach, and in relation to the way the promotion of European audiovisual works has been implemented so far.

This article is organized in different sections that critically offer an overview of current implementation and future changes and challenges regarding the regulation of VOD services under the umbrella of the AVMSD. It will be argued that more interesting than the obligation to comply with a share of European works defined by their geographical origin, is the idea of making VOD service providers part of every national audiovisual production and financing system via financial contributions.

There are basically two ways that could be explored to do so: deriving, totally or partially, the money collected via taxes imposed on providers to a fund dedicated to 
supporting the development of certain audiovisual works (levies; indirect financial contribution), and/or making them invest directly in the production of works by the acquisition of rights and/or (co)production of works (direct financial investment obligation).

What is key is the use given to resources obtained in this way. If a significant part can be destined to independent producers, for example, business concentration can be counterbalanced since this support would allow promoting one of the dimensions that constitute the diversity principle regarding audiovisual industries. Such dimension is related to what Philip Napoli (1999) defines as source diversity, which refers to producers and distributors of content but also to the workforce hired by them.

This reasoning connects with a specific view of what diversity of/in the audiovisual industries should be and with the idea that there are different dimensions regarding the diversity principle. Even though it is evident that the degree of diversity of any audiovisual system depends on a multiplicity of factors, in order to analyse it at least the following must be taken into account (for details see AUTHORS 2017a; 2019):

a) The production, distribution, promotion and exhibition/broadcast of audiovisual works are not concentrated into a reduced number of players. Furthermore, these players can be characterized as evidencing differences in terms of ownership, size and geographical origin.

b) The audiovisual works show differences of variety, balance and disparity in relation to values communicated, identities represented and aesthetics showed. ${ }^{1}$ These works should reflect the multiplicity of groups that coexist in a given society (internal diversity) as well as the cosmogonies and expressions of foreign cultures (external diversity). 
c) Citizens and social groups should have access to a wide range of contents of their choice (access) and, if they want to, should be able to create and disseminate them (participation).

This way of understanding diversity not only aims to reaffirm a holistic perspective on the functioning of the audiovisual industries in the context of dynamic, changing societies but also seeks to focus on the question of power within the diversity/audiovisual industries binomial. In short, a critical understanding of audiovisual diversity should refer more to power relations that give (or do not give) place to differences rather than to differences themselves. This conception aims to transcend specific issues like media ownership, ideas portrayed or modes of consumption as such to focus on a more balanced distribution of communicative power.

It will be concluded that even though both quotas and financial obligations may present implementation issues regarding the regulation of VOD services, the latter, especially indirect obligations, can offer a wider room for manoeuvre to better help focus public policy decisions to protect and/or promote the different dimensions that add up to the diversity of/in audiovisual industries. The levy often referred to as 'Netflix tax', implemented in France and Germany, is here presented as a case in point.

From a methodological point of view, this article draws largely on secondary sources: research was based on documentary and bibliographical review and analysis (legislation, official and industry reports, emerging literature, etc.). On the theoretical level, literature on media diversity and on the implementation of different regulatory mechanisms for intervention, like content quotas and financial contributions, helps present critical considerations of national policy initiatives. Analysis, grounded in 
critical political economy of communication, understands policy as political action market by conflict.

\section{Market failures, diversity and policy}

Designing and implementing policies for audiovisual industries has always been challenging. This has to do with the fact that these industries are not only affected by 'normal' economic and industrial policy considerations (growth, employment, efficiency, etc.), but also by 'special' concerns that stem of the socio-political and cultural importance of media industries (Doyle 2012, 21). The highly contested field of audiovisual policy, where these competing priorities need to be balanced, has tended, in turn, to look for legitimacy in claims derived either from normative political argumentation or economic theory.

As regards economic theory, claims present certain measures, such as content quotas and financial contributions, as appropriate methods to face what is usually known as the problem of market failure in media industries. Edelvold Berg et al. (2013, 107-116) summarize the reasons of why media markets are particularly subject to failures of all types, explaining the distinctive characteristics of media contents as complex goods. Market failure, therefore, is especially to be found when these goods are involved due to five inherent traits:

a) Non-rivalry in consumption, associated with high first-copy cost for production but low marginal costs for additional copies or numbers of consumers.

b) Some degree of non-excludability that mandates the artificial creation of barriers to ensure viability.

c) Value for the individual only known after consumption.

d) High potential for indirect externalities linked with consumption. 
e) Perishable nature of mediated content.

Nonetheless, these scholars also stress the fact that what market failure means is determined by every society's ambitions for its media systems; inherently meaning that normative argumentations are vital to economic theory because they 'legitimate assumptions about how markets should work and ought to be organized' (Edelvold Berg et al. 2013, 106).

So, it is not surprising that, where audiovisual is concerned, it is widely (though not universally) accepted that public interventions are still needed to counteract deficiencies arising from free market functioning, but that interventions also take place for non-economic reasons (Doyle 2012, 17). When action is needed on economic grounds, the mechanisms most frequently used to address market failures refer to regulation. Notably, in the case of the EU, minimum quotas reserved to make national and/or European works accessible, prominence obligations regarding these works and obligations for audiovisual players to invest in indigenous works.

These can be identified inside the increasingly complex support framework that has been created across Europe over the years as part of the EU's policy to support cultural diversity and create a common audiovisual market. Such intervention has been justified because 'European films and other audiovisual works are culturally valuable, they face strong competition from outside Europe, and they suffer from a somewhat weak circulation outside their country of origin' (EAO 2019, 1).

Minimum content quotas, currently intended to be both a cultural policy and a form of industrial protectionism (Broughton 2013), emerged in Europe in the audiovisual field at the beginning of the past century with the aim of ensuring the public dissemination of feature films in the face of the threat of Hollywood works. Since then they have been a long-standing support mechanism to compensate for market failures, 
being mobilized often as a privileged solution to promote and defend cultural diversity (Benghozi 2017).

Today quotas are a protectionist measure to reduce the imports of audiovisual contents from outside the EU while at the same time increase intra-European trade and expose viewers to more content produced in other European countries, thereby helping to cultivate a European cultural identity (Michalis 2014, 135). Basically quotas, and also prominence obligations, try to give an answer to the question: what is the point of getting your film financed if you do not manage to get it shown to an audience? (EAO 2019, 1). Which is why, among advantages, visibility for works and protection for indigenous production are usually invoked to support their existence.

Nevertheless, quotas are also subject to limitations and critics. According to Benghozi $(2017,141)$, their outcomes are spontaneously considered from a positive perspective pointing out noticeable effects (e.g. direct visibility of local content) without taking into account all the indirect ones (e.g. weakness and balkanization of national producers).

Following the summaries Doyle (2002) and Broughton (2013) offer, the following disadvantages can be outlined. Firstly, it should be noted that when quotas restrict the level of time/presence given to foreign works to redistribute demand in favour of local works, they are criticized for impacting on provider's operating costs and generating potential misallocation of resources (domestic prices may be higher and therefore less cost-efficient). Conversely, when they mandate a certain amount of works produced locally, quotas may end up encouraging cheaper produce content affecting, therefore, quality. Secondly, as regards trade, quotas can affect exchanges giving rise to retaliatory measures with the consequent risk of a commercial war. Lastly, 
but not less importantly, quotas do not guarantee the effective consumption of the contents made available.

As we explain later, regarding the regulation of VOD services under the AVMSD, not only supply doesn't guarantee demand, but another two points can be made in relation to quotas: the imposition to include certain works in catalogues will not necessarily translate into their actual visibility, and when obligations are related to the geographical origin of works they may hinder internal as well as external audiovisual diversity (for example, if the respective shares devoted to European and non-European works end up being monopolized by productions from few countries).

It should be noted that quotas can directly influence the diversity of audiovisual works made available to consumers. Nevertheless, evidence regarding their efficiency is not conclusive (Michalis 2014) and, when the nature of empirical results available is considered, it appears debatable (Benghozi 2017). EU quotas, for instance, seem to have done little to encourage the circulation of European works among European countries or the audiovisual production industries in general (Broughton 2013).

Oligations for some players to invest in indigenous works is another important regulatory mechanism designed to foster audiovisual industries as well as cultural diversity (together with public aids, fiscal incentives and guarantee facilities for securing access to private financing). Such financial contributions can be either direct, via the pre-acquisition and/or coproduction of film and TV programmes, or indirect, through a financial contribution to a national audiovisual fund. The latter can be classified as restricted, if the fund has to allocate the money to an agreed project, action and/or activity; or unrestricted, if the fund can allocate the money to projects, actions and activities as it pleases (EAO 2016a, 83). 
As regards advantages and disadvantages, several of the points made vis-àvis quotas can also apply to direct financial contributions: visibility and protection of local works, on the one hand, but impact on operating costs and quality, on the other. Limitations can also be detected for indirect financial contributions: constraints and administrative burdens for SMEs, transfer of the cost of the obligation to third parties (e.g. to consumers via price increases), or discouragement to invest in certain types of works (e.g. non-mainstream contents).

As it is also the case with quotas, evidence regarding the efficiency of financial contributions is scarce, scattered and 'mixed' (see, for example, EAO 2016a, Button 2019). What is interesting, regarding audiovisual diversity, is that financial contributions have the potential to be implemented to influence not only diversity offered but also diversity produced and consumed when, for example, indirect obligations contribute to a fund.

In consequence, a substantial difference could be outlined between direct and indirect financial obligations: whereas the former usually gives autonomy in the management of the investment to those who are obliged to contribute, the latter places the responsibility over the destination and distribution of the money raised on (generally speaking) public or state-owned dedicated bodies. With direct obligations the risk of strengthening market dominance of some players exists. This has been the Spanish case, where commercial broadcasters have concentrated compulsory investments on their own film and television productions - betting on the most popular genres of the local market and promoting them widely -, turning their film subsidiaries into leading companies of the local film industry. On the contrary, in the case of indirect obligations, bodies that manage funds are the ones responsible for establishing different lines of action, taking into consideration non-commercial criteria and 
assigning aids through automatic or selective mechanisms. The French Fonds Images de la diversité, managed by the Centre national du cinéma et de l'image animée (CNC), are a good example of this.

\section{In Search of an Even Playing Field}

During the past years, audiovisual markets have been facing tremendous transformations that are the result of several interrelated and complex long-standing socio-economic processes (AUTHOR 2015, 166-67). Policy has tried to encompass these transformations in a scenario where new online players and business models are re-shaping the structure of the audiovisual markets (Arthofer et al. 2016).

In Europe, where technological and market developments pushed the amendment of the Television without Frontiers Directive since its adoption in 1989, audiovisual media services ended up being regulated differently depending on whether they are linear or non-linear services, that is to say, on-demand or not, while services that did not fall under the editorial responsibility of their providers remained outside the scope of the obligations (e.g. video-sharing platforms). Additionally, the so-called country-of-origin principle has remained at the core of the regulation of audiovisual media services at the EU level. According to this, providers have to abide only by the rules of the state with jurisdiction over them even though they can operate in all Member States. It's worth remembering that this principle doesn't prevent countries from establishing higher standards than those laid down by the AVMSD at national level. But they cannot restrict, in principle, the reception of audiovisual services from another state on the basis of those stricter rules, and therefore cannot prevent that what is known as jurisdiction shopping practices take place. 
Services established outside the EU have of course been always excluded from these obligations, which is why there have been calls since the beginning of the 2010 s to reconsider the country-of-origin principle in the context of the AVMSD. This has been prompted by the (re)location of major US audiovisual companies (e.g. Netflix, HBO or Amazon Prime Video) in 'regulatory heavens' within the EU, enabling them to take advantage of this principle to avoid the heavier regulatory burdens of the countries to which they target their services (Wagner 2014, 286). A mapping of national rules for the promotion of European audiovisual works in Europe (EAO 2019) shows, precisely, the variety of measures in place.

Currently that fierce competition is taking place between incumbent players, that rely on historical distribution models, and emerging pure online players, that develop innovative services, establishing an even level playing field becomes more and more complex. Which is why this is a preoccupation that has been at the core of European audiovisual media policies. In this regard, with the amendment of the AVMSD in 2018, it was stressed that 'the audiovisual media services market has evolved significantly and rapidly due to the ongoing convergence of television and internet services', and that an updated legal framework is required 'to achieve a balance between access to online content services, consumer protection and competitiveness' (EU 2018, Recital 1).

Moreover, this amendment brought many changes to the 2010 text $^{2}$ (ACT 2018; AUC 2018). In search of an even playing field between traditional and new players, the 2018 AVMSD has led to a considerable alignment for linear and non-linear services, and its scope now also covers video-sharing platforms - albeit with different obligations.

During the 2018 AVMSD's revision process the debate about the regulation of audiovisual works offered by transnational VOD service providers was particularly 
intense. As a result, a firm step to impose the logic of content quotas to the catalogues of all VOD services was given. As it's summarized below, the rules for the promotion of European works are changing, being the novelty that VOD service providers have new obligations to promote such works in terms of share and prominence.

\section{The Revised AVMSD: Article 13}

The 2010 version of Article 13 (paragraph 1) established a general obligation to promote production and access to European audiovisual works by non-linear services and left to the states, 'where practicable and by appropriate means', the decision on how to achieve this objective; either through the financial contribution made by these non-linear services to the production and rights acquisition of European works and/or the presence of European works in their catalogue of contents.

The structure of the new Article 13 in the amended AVMSD dedicates a specific paragraph to each of the obligations. If the previous version of the article addressed the share and/or prominence obligation and financial contributions to the production of audiovisual works in the same paragraph, in the new text there is a clear distinction between these two, which are handled in two separate paragraphs. Moreover, it must be underlined that while Article 13 was exclusively dedicated to VOD services, the new version is extended as well to linear services with respect to the financial obligation set out in paragraph $2^{3}$.

In a nutshell, article 13 of the codified version of the reformulated AVMSD (EU 2018), specifies that:

- The quota obligation of European works becomes mandatory with a minimum of thirty per cent; and the prominence for these works has to be ensured. 
- This quota can be filled through locally produced works as well as qualifying titles produced in other EU Member States or European countries participating in the European Convention on Transfrontier Television. The obligation shall not apply to providers with a low turnover or a low audience.

- The Commission still has to issue guidelines regarding the calculation of the share of European works referred to, but also regarding the definition of low audience and low turnover.

- Member States may also waive such obligations or requirements where they would be impracticable or unjustified by reason of the nature or theme of the audiovisual media services.

- Financial contributions to the production of European works remain not mandatory and this applies to linear and non-linear services.

- Such contributions can be done in multiple forms such as direct contributions to the production of and/or acquisition of rights in European works, or levies payable to feed a fund for the audiovisual sector (Recital 36).

\section{Regulation and Quotas of European Works}

Not only quotas for European works but also prominence obligations imposed on VOD service providers are described below, following a mapping elaborated in 2018 by the European Audiovisual Observatory (EAO) for the European Film Agency Directors (EFADs), which considered the situation of the thirty-one countries that are members of the EFADs (EU-28, Iceland, Norway and Switzerland). In three cases, neither quotas nor prominence measures are currently imposed under the umbrella of the 2010 version of the AVMSD: Switzerland, Estonia and the United Kingdom. A summary of 
the situation in other European countries follows (EAO 2019). It remains to be seen how new obligations will be transposed and implemented.

\section{Current Scenario}

As regards quotas, following the 2010 version of the AVMSD, VOD service providers were invited to promote European works by way of access measures, which could potentially include, in the vast majority of cases, a share in their catalogues. As a rule of fact, the 2010 version of Article 13 was transposed without significant modification ('Member States shall ensure that on-demand audiovisual media services provided by media service providers under their jurisdiction promote, where practicable and by appropriate means, the production of and access to European works').

Nevertheless, in thirteen cases more detailed or stricter rules were adopted and a specific quota was imposed to ensure the presence of European works in the catalogues of VOD services. That's why there are various levels of quotas in place. For example: sixty per cent of the cinematographic and audiovisual works featured in VOD catalogues in France; thirty per cent of the works featured in VOD catalogues in the Flemish Community of Belgium, Spain and Italy; or twenty five per cent of the total duration time of the programmes made available in a given calendar year in Hungary (EAO 2019, 94).

As a consequence of the transposition of Article 13 of the 2010 AVMSD too, VOD service providers were invited to promote European works by way of access measures which could include prominence initiatives in the large majority of cases (nineteen out of thirty one). Yet a clear and specific reference to prominence obligations, beyond the wording of the AVMSD, is present in only ten out of thirty one cases. Some of the existing formulations are, for example: 'by highlighting, by way of 
an attractive presentation, the list of available European works', in the French Community of Belgium; 'on their home page, at any moment, reserve a substantial part the exposure European works or works whose original language is French, including by exposing imagery and making trailers available', in France; or 'by adopting functionalities that allow users to search by origin', in Italy (EAO 2019, 98).

\section{New Provisions and Challenges}

Following the European Regulators Group for Audiovisual Services (ERGA 2018), some comments can be made in light of the revised AVMSD that establishes quotas and prominence for European works as compulsory.

As already noted, Article 13, paragraph 1 of the 2018 AVMSD states that it will be mandatory for VOD service providers both to reserve a minimum thirty per cent share of European works in their catalogue and to ensure prominence of these works. This tends to align the non-linear services regime with the one adopted for linear services - even though the shares are different for each category of services.

The means of ensuring prominence may include (Recital 35): providing for a separate section dedicated to European works that is accessible from the service's homepage; giving users the possibility to search for European works in the search tool available as part of the service; using European works in campaigns of the service or a minimum percentage of European works promoted from the catalogue (by using banners, for example).

Nevertheless, there are at least two practical implications for implementation that can be highlighted: the method for calculating the share of European works and the definition of what prominence actually means. 
As regards the former, since the now mandatory minimum share of thirty per cent will have to be applied throughout the single market, and there is no prevailing methodology used for the calculation of this share, issues in terms of consistency in the application of the obligations may arise (referring to calculation but to monitor compliance also).

It should be reminded first that not all countries have implemented the promotion of European works in the catalogue of VOD services in the same way and that certainly not everyone did it in a mandatory way. The existence of diverse policies presents various levels of experience with implementing share-like obligations. As explained, some countries did not use any quota for European works and others included it only as an alternative.

Additionally, the methods for calculating the share of catalogue are not homogenous: they are usually either on the basis of the number of hours or on the basis of the number of titles. And there is the question of whether some audiovisual genres or programmes within non-linear services should be excluded from the share as can be the case with linear offerings (e.g. some countries exempt news programmes, sports events, games or current affair programmes).

The European Commission (EC) will have to issue guidelines regarding the calculation of the share of European works (Article 13, paragraph 7). The challenge is obvious: in a scenario with a patchwork of policies already implementing share obligations, a consistent calculation method must be ensured across the EU market (despite states may choose not to impose the same quota; the share of thirty per cent European works is minimum). If some form of harmonization is not achieved, there is a risk that transnational VOD service providers take advantage of regulatory asymmetries in the EU single market. 
In relation to the definition of prominence, it should be noted that, like the 2010 version, the reformulated AVMSD does not provide one. Therefore, despite the examples given in Recital 35, states will have to develop their own approach to the issue over the course of the transposition period.

There are many concerns that there might not be a consistent implementation of this provision across the EU. Not only because very few regulators check prominence (being it mandatory in a small number of countries), but also because some of the challenges in this respect arise from the fact that VOD services evolve and they include innovations (e.g. voice-driven search). How prominence can be achieved today may be very different from how it can be achieved in five years.

\section{Long Live the Quota System?}

As advanced, even though with regard to audiovisual diversity quotas could positively influence diversity offered, a critical consideration of share and prominence obligations, especially in relation to the regulation of VOD services, leads us to make at least three points: the imposition of quotas related to the geographical origin of the works may hinder external audiovisual diversity; the obligation to include certain audiovisual works in catalogues will not automatically translate into their consumption; and it will certainly not translate into their actual visibility either.

Firstly, the imposition of quotas related to the geographical origin of the works is a protectionist measure, linked to the defence of national audiovisual sovereignty, that splits the universe of creations in two opposite poles: in the case of the EU, 'European versus foreign'. In this sense, it is a measure that does not favour external audiovisual diversity. 
Perhaps a more effective approach would be to establish minimum quotas for national/European productions and maximum quotas for foreign productions, equally applied to every country. That is to say, it could be proposed that works originating from a particular country should not make up more than a certain amount of a given catalogue (e.g. twenty per cent). Without neglecting that there is a debate about what defines the nationality of an audiovisual work, this type of measure could help to avoid that non-European productions are monopolized by a single country or a few. If external diversity wants to be promoted, balanced catalogues are to be achieved across different geographical origins.

Secondly, it must also be taken into consideration that the obligation to include European works in catalogues will not automatically translate into their consumption. Even though the availability of works is a conditio sine qua non for its potential consumption, nothing can predict that it will actually take place. Supply doesn't guarantee demand: the consumption of works will depend on their quality, proper promotion and potential appeal.

Let's give an example regarding quality and/or appeal. In the EU, it is still unknown how big transnational players will reach the target set for share obligations. A research released by Ampere Analysis in September 2018 calculated that a company like Netflix, with European content accounting for fifteen per cent of its online catalogue in the United Kingdom, would need to make or acquire nearly 800 new films or television series, more than 4,000 hours of content, for its service to reach the thirty per cent quota imposed by the 2018 AVMSD (Varatharajah 2018). For its part, the American Computer and Communications Industry Association predicted that the mandatory requirement to include a minimum thirty per cent share of European works 'could either force US companies to buy large volumes of inexpensive European 
content or to reduce the number of non-European works in their catalogues' (CCIA $2018,48)$. So, we could be facing a future scenario in which transnational VOD service providers comply with the quota imposed by acquiring cheap works of little value and/or interest for their respective catalogues. Such an unintended outcome would have a perverse effect in relation to the goal of connecting citizens with series and movies imagined and conceived in their respective countries and/or regions.

Finally, and in direct relation to the works' availability of a certain geographical origin in the VOD service providers' catalogues, beyond prominence the issue of their actual discoverability arises. It is key to avoid that national and/or European works have little visibility within catalogues made up of thousands of titles, or that they are marginalized as low-profile niches. Promotion therefore is also key.

\section{Regulation and Financial Contributions}

It is here argued that more interesting than the obligation to comply with a quota defined by the geographical origin of audiovisual works, is the idea of making transnational VOD service providers part of every national audiovisual production and financing system via direct and, especially, indirect contributions. The reasoning behind is that even though any measure regarding the regulation of contents offered within catalogues will present challenges, the latter could offer a wider room for manoeuvre to strengthen the diversity of/in audiovisual industries.

The overview offered below, following also EAO (2019), shows that there are basically two ways that could be explored in order to do so: deriving, totally or partially, the money collected via taxes imposed on VOD service providers to a fund dedicated to supporting the development of audiovisual works (levies; indirect financial contribution), and/or making them invest directly in the production of audiovisual works 
by the acquisition of rights and/or (co)production of works (direct financial investment obligation).

Beyond the amendment of the AVMSD, also analysed here, the implementation of the so-called 'Netflix tax' in some countries can be seen as an interesting example of the fact that VOD services offered by transnational companies could be regulated in a more clear and straightforward way.

\section{Current Scenario}

Taking into consideration direct contributions, financial investment obligations are currently imposed on VOD service providers in only ten out of thirty one cases (EAO 2019, 64). The only seven countries where mandatory financial obligations are imposed on VOD services are Denmark (as of 2020), Spain, France, Germany, Greece, Italy and Portugal; and in three cases the obligation is not mandatory but optional. That is the case of Belgium (French and Flemish communities), where VOD service providers can choose between the financial investment and paying a levy, and Czech Republic and Slovenia, where providers can choose between the financial investment and quotas for European works in their catalogues. In ten other cases, the legal framework is only a transposition of the formulation of Article 13 of the 2010 AVMSD or a similar formulation that does not imply a financial investment obligation: Cyprus, Finland, Croatia, Ireland, Lithuania, Luxembourg, the Netherlands, Norway, Romania and Sweden.

When indirect contributions are considered, levies are imposed on VOD service providers in only seven out of thirty one cases (EAO 2019, 73). Peculiarities are as follows: in some of these, the obligation is not mandatory but optional; the amount due by providers represents a percentage of the turnover/revenues raised from the service 
they offer (between 0.5 per cent and 3 per cent); and in all cases the beneficiary is the national/federal film/audiovisual fund. The levy is also applicable to foreign providers targeting the domestic audience in the following three cases: the Flemish Community of Belgium, Germany and France.

\section{New Provisions and Challenges}

The 2018 AVMSD has not turned financial contributions into mandatory measures, though some changes have been introduced. The new Article 13 recognizes the possibility for states to impose financial contributions, which can be done in multiple forms. Important changes as compared to the 2010 AVMSD are:

a) Countries which impose financial contributions on media service providers under their jurisdiction may also require contributions from providers targeting their audiences even though they are established in another state; and such measures should be non-discriminatory and proportionate.

b) Only the revenues generated in the country will be considered eligible, and, in order to avoid double imposition (Recital 39), financial contributions imposed by targeted countries shall be taken into account by the state having jurisdiction. Nevertheless, there is no detailed prescription about how states should calculate the financial contribution that targeting service providers would have to make under this kind of setting.

EU states have the obligation to exempt specific categories of VOD audiovisual service providers in case of low turnover and low audience. And also have the possibility to exempt those for which the obligations foreseen would be 'impracticable or unjustified by reason of the nature or theme of the service' (EU 2018, paragraph 6). 
The exemptions apply to the obligations set out in Article 13, paragraphs 1 and 2, the latter only for services established in another state.

Recital 40 of the 2018 AVMSD states that the aim is to not undermine market development and to allow for the entry of new players, and provides some guidance about how to determine whether a service provider has a low turnover and/or low audience. A low audience can be determined, for example, on the basis of a viewing times or sales, while the determination of low turnover should take into account the different sizes of audiovisual markets in EU countries. It is foreseen that the EC issues guidelines on this issue.

Looking into implementation issues, while bearing in mind the great variety of existing national financial contribution schemes, the imposition of cross-border financial contributions that are not mandatory presents mainly three challenges: the data collection and treatment, the conceptualization and determination of 'targeting', and the lack of enforcement procedures foreseen (ERGA 2018, 11).

The collection and diligent verification of economic data allowing states to calculate the financial contribution that targeting service providers would have to pay (e.g. on the basis of the revenues earned in a targeted country) may not be easy. Some audiovisual media service regulators, for example, may not have the mandate or adequate resources to request all the relevant information that another regulator in the targeted country would need.

Determining whether a VOD service is targeting audiences in several territories will be difficult. Firstly, because the term 'targeting' is not legally defined in the 2018 AVMSD (therefore open to various interpretations). ${ }^{4}$ Secondly, because both states the one targeted and the one having jurisdiction - may agree that a VOD service is targeting a specific market but may have different views regarding the categorization 
of that same service as an VOD media service (e.g. should catch-up TV services contribute if they are merely rebroadcasts of linear contents?).

Last but not least, since the 2018 AVMSD does not impose financial investment obligations, Article 13 does not deal with sanctions and is silent with regard to situations where a given VOD service provider would not comply with the financial obligations imposed. Therefore, it is unclear which country would be responsible to address a case.

\section{From Quotas for European Works to Financial Contributions?}

Among those EU countries that impose financial obligations on the providers of ondemand audiovisual services, as of December 2018 only four had a so-called 'Netflix tax' in place: The Flemish Community of Belgium, Italy, France and Germany (Donders et al. 2018). These are countries that already imposed obligations for non-domestic VOD services providers.

As Karen Donders and her colleagues pointed out (Donders et al. 2018), as well as the European Audiovisual Observatory (EAO 2016b; 2019), the German and French cases have special characteristics: if the former is the only country that has a levy to be paid to a film fund, the latter went beyond the scope of the then in force 2010 AVMSD when decided that any VOD service provider had to contribute irrespective of editorial responsibility over the service (e.g. including YouTube).

These two cases are also examples of the fact that the imposition of financial contributions could help regulate VOD services offered by transnational companies in a very straightforward while flexible way when there is political will to do so.

\section{France}


Under the motto tous les diffuseurs financent la création, France became a pioneer country imposing payment obligations on VOD service providers, including video sharing platforms targeting French audiences (something out of the scope of the AVMSD until now), whether they were established in the country or not, and whether they offered services free of charge or not.

The Taxe sur la diffusion en vidéo physique et en ligne de contenus audiovisuels (or Taxe Vidéo et VOD), is one of the three taxes that contribute to the financing of the fund reserved for the audiovisual sector managed by the Centre national du cinéma et de l'image animée $(\mathrm{CNC})^{5}$, an agency of the French Ministry of Culture. This tax applies to service providers that sell and rent physical and online audiovisual content in France (General Tax Code, Article 1609 sexdecies B). Upon receiving the EC's approval, an extension to the Taxe Vidéo et VOD came into force on 21 September 2017 (Decree No. 2017-1364), so that foreign companies offering audiovisual services in France (e.g. Netflix or YouTube) are also obliged by the tax.

Since then, services that make available or give access to audiovisual works to the audience in France have to pay a tax. This two per cent tax, calculated on the basis of net annual turnover, is applicable to: sales and rentals of videograms (physical and online) intended for private use of members of the public; paid services providing individual access to audiovisual works in response to an individual request made by electronic means; and sums paid by advertisers and sponsors to services providing individual access to audiovisual works for free, in response to an individual request made by electronic means. This two per cent rate is raised to ten per cent when the transactions concern audiovisual works of a pornographic nature or incitement to violence. 
After months-long discussions with the CNC's authorities, at the beginning of the autumn 2018 Netflix's executives revealed that the company had agreed to start paying the tax. These new resources - the CNC is expected to receive two million euros from Netflix and two and a half million euros from YouTube (Kesslasy 2017) will nourish the existing audiovisual support in France for films, TV series or videogames.

\section{Germany}

In Germany, the Film Support Act (Filmförderungsgesetz, FFG), first enacted in 1967, requires broadcasters, cinema operators, video distributors and VOD service providers to financially contribute to the promotion of the film industry. This law stipulates the measures for the promotion of German cinema and details the conditions for audiovisual support given by the German Federal Film Board (Filmförderungsanstalt; FFA).

The existing funding scheme for film production, distribution and exhibition, is financed through a 'special levy' (sonderabgabe) that is imposed on undertakings in the cinema and video industry and the broadcasting sector. VOD service providers, as well as cinema operators and video suppliers have to pay a compulsory levy to the FFA based on their incomes from film exploitation. VOD service providers are taxed based on their net annual turnover, provided it exceeds fifty thousand euros. But only suppliers of VOD services with a registered office or branch office in Germany had originally to pay the film levy - consistently, only those registered could apply for audiovisual support from the FFA.

In July 2013, the FFG was amended so that VOD service providers not established in the country could be subject to the film levy, which would apply to the 
income that such providers derive from selling services on German-language websites to customers in Germany.

This extension was justified as follows (EAO 2016b, 72):

a) due to the context of rapid technological developments, particularly in the distribution of films, with an increasing share of on-demand access to films;

b) to take into account major global VOD players which serve different countries from a single establishment located in an EU country; and,

c) to remain in line with the existing system and philosophy of the FFG, whereby the consumption of films in Germany on any carrier ensures income for a government-owned fund, which supports various cultural objectives including films production and distribution.

Germany notified the amendment to the FFG to the EC on March 4, 2014. The Commission initially expressed its doubts, but after Germany complied with the procedure of sending observations and receiving comments from interested parties, the amendment was eventually accepted as compatible with the Treaty on the Functioning of the European Union (EU 2012) and the AVMSD (EC 2016).

In February 2019, it was known that Netflix, offering its VOD service aimed at German audiences since 2014, intended to start paying the film levy in September 2019. This could mark the end of a legal dispute that has lasted several years concerning the company's obligations under the FFG. Netflix must pay a levy based on the net turnover generated by its customers in Germany for any cinematographic work. ${ }^{6}$

As Christina Etteldorf $(2019,1)$ explains, 'the film levy is worth 1.8 per cent of the first 20 million euros of annual revenue generated in Germany and 2.5 per cent of annual revenue above 20 million euros'. Beyond the global revenue reported by Netflix 
in 2018 , of around 15 billion US dollars in 2018, figures for individual (national) markets are not published. Therefore, it is difficult to calculate how much it will owe: the sum that Netflix will ultimately pay remains to be seen.

\section{Final Remarks: the 'Netflix Tax' as a Case in Point}

Beyond what the 2018 amendment of the AVMSD may bring, with financial contributions allowed (but not mandated) to be imposed on VOD service providers, French and German policies can be cited as examples of the fact that the imposition of indirect financial contributions could help to regulate VOD services offered by transnational companies in a very clear and straightforward way if there is political will to do so. As explained, a mandatory quota to secure a minimum share of European audiovisual works can be decaffeinated in many ways or end up having unintended side effects.

Without neglecting that policies based on financial contributions have to face specific challenges too, many already outlined, investment obligations, especially when they are indirect, can offer a wider room for manoeuvre to protect and/or promote the different dimensions of the diversity of/in audiovisual industries. That is to say (and simplifying): diversity produced, offered and consumed. This is so because they are a more useful mechanism to make VOD service providers part of national audiovisual production and financing systems since they can be designed to achieve clear and straightforward aims.

What is key, to avoid that this type of decision ends up being blurred or having unintended side effects, is that, for example (and at least), a significant part of resources obtained from the compulsory contributions of the new players can be destined to support audiovisual works produced and distributed by independent 
companies, and that tax forum shopping is constrained by building a well-designed targeted country approach.

If states impose direct financial obligations on VOD service providers established in other EU countries, for example, jurisdiction shopping practices can be mitigated or, at least, tax asymmetries can be compensated. In addition, if a tax-based financial contribution exists, and money is collected for a fund that supports audiovisual works produced and distributed by independent companies, a rather straightforward way to make VOD service providers contribute to the production of European works can be achieved.

It should be stressed that the supremacy of financial contributions against a quota for European works is not defended here. It's not argued that the former are better than the latter in the sense that one option is better than the other per se. Depending on implementation, quotas may perfectly serve to promote diversity offered. The point to be made is that imposing financial contributions is a more straightforward while flexible mechanism, especially in the case of indirect alternatives, with implementation possibilities that rely on regulators rather than on providers. In that sense, diversity consumed and produced could also be influenced.

Additionally, unlike quotas, usually based on quantity rather than quality as well as on the origin of the production and not the characteristics of the product, financial obligations could help protect and/or promote audiovisual diversity in a more integral way without discriminating foreign works and, at some point, erect trade barriers. In other words, they could better help balance industrial and cultural policy goals.

Furthermore, direct or indirect financial contributions should be coordinated with quotas when both (or any other) types of mechanisms exist. Why? Because it's not about mechanisms but policy goals. At the end of the day what matters is the policy 
tool-kit in place. The fact that effects of regulatory mechanisms for intervention are not easy to evaluate shouldn't put economic claims out of the picture to legitimate policy decisions. But if we agree on the fact that market failures do not disappear in a scenario in which the increasing consumption of audiovisual works via on-demand services provided transnationally is new to the equation, the need for intervention exists and regulatory mechanisms have to be justified also on non-economic grounds.

\section{References}

ACT (Association of Commercial Television in Europe). 2018. "A practitioners guide to the reform of the EU Audiovisual Media Services Directive". Accessed November 9. https://acte.be/uploads/Modules/Mediaroom/180614---apractitioners-guide-to-the-reform-of-avmsd.pdf

AUTHOR. 2015. "Digital Networks and Services: A New Political and Technological Agenda". In Power, Media, Culture. A Critical View from the Political Economy of Communication, edited by Luis A. Albornoz, 165-168. London: Palgrave Macmillan.

AUTHORS, editors. 2017a. El audiovisual en la era digital. Políticas y estrategias para la diversidad. Madrid: Cátedra.

editors. 2017b. Diversidad e industria audiovisual: el desafío cultural del siglo XXI. Mexico City: FCE.

2019. "Audiovisual Diversity in the Digital Era: Trends and Prospects". In Audiovisual Industries and Diversity: Economics and Policies in the Digital Era, edited by Luis A. Albornoz, and María Trinidad García Leiva, 185-200. London/New York: Routledge. 
Arthofer, Frank, Hararson, Áki, Kon, Martin, Lee, Eric, and Rose, John. 2016. The future of television. The impact of OTT on video production around the world. New York: The Boston Consulting Group.

AUC (Asociación de Usuarios de la Comunicación). 2018. La nueva directiva de servicios de comunicación audiovisual. Análisis y comentarios. Madrid: AUC.

Benghozi, Pierre-Jean. 2017. "What Efficiency and What Future for the Cultural Quotas in the Digital Age?" DigiWorld Economic Journal, 107 (3rd Q.): 139-161.

Broughton Micova, Sally. 2013. "Content quotas: what and whom are the protecting?". In Private Television in Western Europe: Content, Markets, Policies, edited by Karen Donders, Caroline Pauwels, and Jan Loisen, 245-259. Hampshire: Palgrave.

Button, Patrick. 2019. Do Tax Incentives Affect Business Location and Economic Development? Evidence from State Film Incentives. IZA Discussion Paper No. 12225, Bonn, March.

CCIA (Computer and Communications Industry Association). 2018. Comments of the Computer \& Communications Industry Association Regarding Foreign Trade Barriers to U.S. Exports for 2019 Reporting. Washington DC, 30 October. Donders, Karen, Raats, Tim, Komorowski, Marlen, Kostovska, Ivana, Tintel, Stephanie and lordache, Catalina. 2018. Obligations on on-demand audiovisual media services providers to financially contribute to the production of European works. An analysis of European Member States' practices. Brussels: Centre for Studies on Media Innovation and Technology (SMIT).

Doyle, Gillian. 2002. Understanding Media Economics. London: Sage.

Doyle, Gillian. 2012. "Audiovisual economics: Audiovisual markets in the European Union”. Quaderns del CAC, 15(38): 15-23. 
EAO (European Audiovisual Observatory). 2016a. Public financing for film and television content. The state of soft money in Europe. Strasbourg: EAO. 2016b. "VOD, platforms and OTT: which promotion obligations for European works?" IRIS Plus 2016-3. Strasbourg: EAO.

2019. Mapping of national rules for the promotion of European works in Europe. Strasbourg: EAO.

EC (European Commission). 2016. Commission Decision of 1.9.2016 on the Aid Scheme SA.38418 - 2014/C (ex 2014/N) which Germany is planning to implement for the funding of film production and distribution. C(2016) 5551 final. Brussels. Accessed November 9. http://docs.vlaamsparlement.be/pfile?id=1350346

Edelvold Berg, Cristian, Ferrell Lowe, Gregory, and Brink Lund, Anker. 2014. "A Market Failure Perspective on Value Creation in PSM". In The Value of Public Service Media RIPE@2013, edited by Gregory Ferrell Lowe and Fiona Martin, 105-126. Gothenburg: Nordicom.

ERGA (European Regulators Group for Audiovisual Media Services). 2018. "ERGA Analysis \& Discussion Paper to contribute to the consistent implementation of the revised Audiovisual Media Services (AVMS) Directive". Accessed November 9. http://erga-online.eu/wp-content/uploads/2018/11/ERGA-2018-08-SG3-Analysisand-Discussion-Paper.pdf

Etteldorf, Christina. 2019. "Concession in longstanding German film aid dispute: Netflix will pay film levy". IRIS 4: 1/9. Accessed November 9. https://merlin.obs.coe.int/iris/2019/4/article9.en.html

EU (European Union). 2012. Consolidated versions of the Treaty on European Union and the Treaty on the Functioning of the European Union. Official Journal C 326, 26/10/2012 P. 0001 - 0390. 
2018. Directive EU 2018/1808 of the European Parliament and of the Council of 14 November 2018 amending Directive 2010/13/EU on the coordination of certain provisions laid down by law, regulation or administrative action in Member States concerning the provision of audiovisual media services (Audiovisual Media Services Directive) in view of changing market realities. November 28. L 303/69. Official Journal of the EU.

Kesslasy, Elsa. 2017. "Netflix, YouTube to Pay Tax on Turnover in France under New Law". Variety. September 21.

Michalis, Maria. 2014. "Focal Points of European Media Policy from Inception till Present: Plus ça change?" In The Palgrave Handbook of European Media Policy, edited by Karen Donders, Caroline Pauwels, and Jan Loisen, 128-142. Hampshire: Palgrave.

Napoli, Philip Michael. 1999. "Deconstructing the diversity principle". Journal of Communication, 49 (4): 7-34.

Stirling, Andrew. 1998. "On the Economics and Analysis of Diversity". SPRU Electronic Working Paper, 28. Brighton: University of Sussex. 2007. "A General Framework for Analysing Diversity in Science, Technology and Society". Journal of the Royal Society Interface, 4 (15): 707-19.

Varatharajah, Alexander. 2018. "Euro content bonanza: SVoD giants face adding hundreds of titles to meet EU quotas". Ampere Analysis, September 19. Wagner, Michael. 2014. "Revisiting the Country-of-Origin Principle in the AVMS Directive". Journal of Media Law, 6 (2): 286-304.

\section{Notes}


${ }^{1}$ In relation to the differences that audiovisual works may present, to define variety, balance and disparity one should turn to Andrew Stirling $(1998,2007)$, who understands diversity as a mix of these three components.

${ }^{2}$ The revision was proposed by the EC in May 2016 and, since then, it was subjected to intense negotiations between the co-legislators. With the Commission's support, these negotiations were concluded with the informal agreement on the proposed rules reached on 6 June 2018. On 6 November 2018, the European Council adopted the revised AVMSD reaching the final step in the legislative process. The directive entered into force in December 2018 and EU states have until September 2020 to transpose it into national legislation.

3 It is worth mentioning that the 2010 AVMSD (Recital 69), in some way, advanced the distinction between prominence and financial obligations when distinguished different ways to support European works:

${ }^{4}$ Recital 42 provides guidance for the assessment, on a case-by-case basis, whether a broadcast by a media service provider is 'wholly or mostly directed' towards the territory of another Member State.

${ }^{5}$ Being the other two the Taxe sur les éditeurs et distributeurs des services de télévision and the Taxe sur le prix des entrées aux séances organisés par les opérateur d'établissements de spectacles cinématographiques.

${ }^{6}$ For more detail see Sections 150 and 153 of the FFG. 